\title{
Developments
}

\section{Liability for Online Services in Germany}

\author{
By Thomas Hoeren
}

\section{A. Introduction}

With a growing number of online services which aim to offer their product to a global audience, it becomes increasingly more important to keep informed about the rules and guidelines regulating this business within the countries of the targeted audience. The following article explains the main rules of liability for online services in Germany with special regard to the Telemedia Act.

\section{B. Conflict of Laws}

It is questionable which guidelines on the conflict of laws are decisive concerning the applicability of provisions of tort law; here one should observe Art. 40 EGBGB (Einführungsgesetz zum Bürgerlichen Gesetzbuch; Introductory Act to the German Civil Code). According to this section the injured party has the choice between the law of where the act took place or where the result took place; in addition, this choice of law has to be exercised until the beginning of the oral negotiations. Where the "act" took place usually refers to the location of the provider's server, whereas the "result" usually refers to where the homepage can be accessed. In this respect, several courts apply the "intended" access test.

\section{The Telemedia Act (TMG)}

The liability of providers is now uniformly regulated by the Telemedia Act (TMG); the distinction between teleservices (TDG) and mediaservices (MDStV), which used to be required, is now no longer necessary. The TDG originates from the year $1997 .{ }^{1}$ At that time it formed part of a larger bundle of laws - the so-called Act on Information and Communications Services (Informations- und Kommunikationsdienste-Gesetz; luKDG) though it had to be later revised due to the guidelines in the e-Commerce Directive. ${ }^{2}$ The current version, which is contained in the so-called Act on Electronic Commerce

*hoeren@uni-muenster.de

${ }^{1}$ BGBI. I, 1870.

${ }^{2}$ See Bröhl, MMR 2001, 67. 
(Elektronischen Geschäftsverkehrsgesetz; EGG), came - in its most important parts - into force on the $21^{\text {st }}$ of December 2001. The Sections relevant for liability (Sections 8-11 TDG and Sections 6-9 MDStV) were transposed into the TMG without any change to their content.

The TMG contains rules for criminal and civil law, which are to be considered as a filter prior to the application of specific rules on liability. ${ }^{3}$ The application of these rules was disputed where copyright law was concerned as the Higher Regional Court of Munich (Oberlandesgericht München; OLG München) - in a somewhat controversial decision excluded the application due to the wording and the history of Section 5 TDG (former version; Section 8 of the new version of the TDG, now Section 7 TMG). ${ }^{4}$ However, today, this question has been clarified in favor of the application.

In the TMG there are four types of service providers that are named: Section 7 TMG covers service providers who keep their own information ready for use; Section 8 TMG concerns service providers who transfer third party information or arrange access to their use; a subset of these service providers is represented by those who - according to Section 9 TMG - automatically temporarily store third party information in order to make the transfer of the third party information more efficient; and Section 10 TMG concerns those service providers who save third party information for the user. The law thus differentiates between three different providers: the Content-Provider (Section 7 (1) TMG), the AccessProvider (Sections 8, 9 TMG) and the Host-Provider (Section 10 TMG).

\section{The Content Provider}

The Content Provider, i.e. the one who makes his own information available for use, is an information provider. If one offers a homepage on the internet, then he is responsible for its content. The TMG - in Section 7 (1) - declaratively refers to the "general laws." The EC Directive and the EGG do not change this legal situation and as such, the tenet of the Content Provider's liability remains unchanged according to the general legislation. In practice, it is important to make a clear distinction on the homepage of one's own information and that of third parties:

"You are now leaving our homepage. The responsibility for the content of the following site is held by the provider. We do not assume any liability."

\footnotetext{
${ }^{3}$ Now BGH, MMR 2004, 166 with comments Hoeren.

${ }^{4}$ OLG München, WRP 2001, 578; the decision was not accepted for review by the Federal Court of Justice. See also Schaefer/Rasch/Braun, ZUM 1998, 451; Waldenberger, MMR 1998, 124, 127. But see Spindler, CR 2001, 324.
} 
According to the somewhat questionable view of the Regional Court in Hamburg (Landgericht Hamburg; LG Hamburg) ${ }^{5}$ third party information is also classed as one's "own" information if the operator of an internet site has made this information available to others through his own web page. It further argues that it is irrelevant that a third party may have placed the specific information. This is supposed to be the consequence of the fact that the owner of the respective internet domain is the legally responsible person for the content that is circulated via the website in question. One can first no longer speak of one's own information when the owner of the internet site specifically and expressly distances himself from the particular statement without applying an overall clause that covers everything.

With respect to the liability of content providers, one would have to bear in mind the following general thoughts. First of all, one has to consider the liability for the lawfulness of the content (for instance with respect to breach of copyright) and for the accuracy of the content.

Special legislative provisions on liability are applicable for lawfulness of the content, for example:

- Section 97 UrhG (Urheberrechtsgesetz, Copyright Act) for breaches of copyright

- Sections 14, 15 Markeng (Markengesetz; Trademark Act) for questions pertaining to domains

- Section 7 BDSG (Bundesdatenschutzgesetz, Federal Data Protection Act) for infringements of data protection, or

- Sections 3, 5 UWG (Gesetz gegen den unlauteren Wettbewerb, Unfair Competition Act) for unlawful marketing measures on the internet.

Liability for incorrect content on the part of the Content Provider can arise in accordance with the Product Liability Act or under Section 823 (1) BGB (Bürgerliches Gesetzbuch; German Civil Code). The "Stock Service" jurisprudence could also be used for holding the issuer of print media liable; ${ }^{6}$ however, this case is characterized by a permanent - though similar in nature to a subscription - contract that arose between the issuer and the customer and which was influenced by advisory elements. ${ }^{7}$ For this reason, this decision can only be drawn upon for the user's relationship to a non-gratuitous online information service.

Apart from a contractual link, it is possible that liability comes into consideration only for the breach of an absolute legal interest. The Federal Court of Justice (Bundesgerichtshof;

\footnotetext{
${ }^{5}$ LG Hamburg, MMR 2007, 450.

${ }^{6} B G H$, NJW 1978, 997.

${ }^{7}$ See also Hopt, Festschrift für Fischer 1979, 237; Köndgen, JZ 1978, 389.
} 
BGH) emphasized in the "Table Salt" decision that both the author, as well as the publisher, have to be responsible for incorrect information in medical publications: where medical information is concerned it does indeed lead to injury to body and health, both of which are protected legal interests in terms of Section 823 (1) BGB. Consequently one can expect a high risk of liability when health tips and medical advertising are made available.

The same is also true when downloading software from the internet: if this leads to a loss of data, then a breach of the right of property is present with respect to the user's hard drive no longer being in perfect working order. However, the liability for the loss of data can be withdrawn by the provider through reference to the user's predominant contributory negligence (under Section 254 (1) BGB) as the damage is clearly due to a lack of a back-up of the data.

Clear warnings on the homepage are of importance:

"We do not guarantee the accuracy and entirety of the information found on this homepage."

Furthermore, one has to consider that the Content Provider can rely upon the regular update of the search engines' databases. Once he has thoroughly deleted/corrected his page he therefore does not have to examine whether the disputed internet site still exists, after a period of time, with the operators of the search engines. ${ }^{8}$ The Content Provider does, however, take into account for the actual change to the homepage as the mere removal of the link does not suffice. ${ }^{9}$

\section{The Access Provider}

According to Section 5 (1) TDG (old version) the Access Providers who offer internet access, are not responsible for the extent of the accessible offers. ${ }^{10}$ Nevertheless, attempts were made in part by complicated structures (responsibility under Section 5 (4) TDG (old version, and the general criminal provisions on knowledge of unlawful content, ${ }^{11}$ complicity with the actual Host Provider) $)^{12}$ to make the Access Provider responsible for the content that

\footnotetext{
${ }^{8}$ OLG Hamburg, CR 2003, 66 with comment Dieselhorst. But see LG Frankfurt a.M., CR 2000, 462; LG Mannheim, CR 1998, 306 - Arwis with comment Hackbarth.

${ }^{9}$ LG Hamburg, MMR 2004, 195.

${ }^{10}$ So expressly the $B G H$ for network carriers and their liability in connection with telephone sex charges, MDR 2002, 264 = MMR 2002, 91 with comments Müller .

${ }^{11}$ Order for withdrawal of prosecution of the Federal Attorney General, MMR 1998, 93 with critical comments Hoeren.

${ }^{12}$ AG München, NJW 1998, 2836 (CompuServe) = MMR 1998, 429 with critical comments Sieber.
} 
was stored on servers other than its own. Although these views clearly contradict the legislators' intent, they have not, however, been able to become further established.

The startling conviction of the former director of CompuServe by the Local Court of Munich (Amtsgericht München; AG München) was correctly overturned by the appeal. ${ }^{13}$ The indemnity from the responsibility is also applicable to the content stored on Proxy Servers as the legislation expressly excludes the automatic and temporary storage of third party content (Section 5 (3) $2^{\text {nd }}$ Sentence TDG (old version)).

The provisions that have taken effect since January 2002 are Sections 9 and 10 TDG (new version) and Sections 8 and 9 TMG, which both transpose Art. 12 of the e-Commerce Directive. According to these provisions the Service Provider is exempted from the responsibility for the transmission of information (Section $8 \mathrm{TMG}$ ); the transmission is only present when it concerns the transfer of user information or for mediating access to a communications network. The transmission may not have been brought about by the Service Provider himself: only passive and automatic procedures are sanctioned $\left(42^{\text {nd }}\right.$ recital of the preamble to the Directive). Special provisions regulate the concept of caching (Section 9 TMG). The indication given in Section 7 (2) $2^{\text {nd }}$ Sentence TMG is also especially problematic, as the obligations under general legislative provisions to remove or block remain unaffected. This remark contradicts the e-Commerce Directive and once again evokes the Access Provider's undefined responsibility via the back door. In doing so, it is especially pernicious that the legislation no longer contains the remarks on the technical possibility and economic reasonableness that used to be found in the TDG. Thus, one could interpret that the Access Provider may be unrestricted in blocking, due to an order from the courts or the authorities. However, the principle of "impossibilium nemo obligator" is also applicable here. It is not possible to require the Access-Provider to block when this is not possible; and attempts, for instance by the Regional Government of Dusseldorf (Bezirksregierung Düsseldorf) ${ }^{14}$ to compel blocking are therefore unsuccessful. These blocks can be avoided by simply registering another domain server.

The freedom for the Access Provider is, however, becoming ever tighter due to the pressure exerted by the Content Industry. The industry wants to force the Access Provider to block the access to those disliked possibilities to download from abroad and to release the information on the user's identity, particularly those users of P2P services. Similar measures are also provided by Art. 8 (3) of the Directive 2001/29/EC, which provides that the Member States have to provide effect safety measures against the Access Providers in the fight against piracy: an obligation for the Access Provider to block and release

${ }^{13}$ LG München, MMR 2000, 171.

${ }^{14}$ See Engel, supplement for MMR 4/2003; Mankowski, MMR 2002, 277; Stadler, MMR 2002, 343 et seq. See also OVG Münster, MMR 2003, 348 with comment Spindler/Volkmann; VG Düsseldorf, MMR 2003, 205 with comment Stadler; VG Köln, MMR 2005, 399. 
information that has been derived in lieu thereof. The Federal Ministry of Justice planned to expressly incorporate such an obligation in the UrhG in the course of the second body of legislation. As has been shown, the transposition of Art. 8 (1) (c) of the Enforcement Directive (2004/48/EC) has now introduced a claim for release of information against the Access Provider in Section 101 (2) UrhG and in other rights over immaterial interests (Section 104b PatG-E (Entwurf zum Patentgesetz; Draft Patents Act), Section 24b GebrMGE (Entwurf zum Gebrauchsmustergesetz; Draft of Industrial Property Act), Section 19 MarkenG-E (Entwurf zum Gesetz über den Schutz von Marken und sonstigen Kennzeichen; Draft Trademark Act), Section 46 GeschMG-E (Entwurf zum Gesetz über den rechtlichen Schutz von Mustern und Modellen; Draft of Act of legal protection of patterns and models), Section 9 HalbISchG-E (Gesetz über den Schutz der Topographien von mikroelektronischen Halbleitererzeugnissen; Draft on the protection of the topography of micro-electronic semi-conductors), Section 37b SortSchG-E (Entwurf zum Sortenschutzgesetz; draft on plant variety protection). However, the courts do not view the Access Providers duty to block as being given de lege lata. ${ }^{15}$ On the one hand, the providers are neither perpetrator nor participant with regard to the infringement in that they have no access to the internet sites with incriminating content. On the other hand, the liability as a so-called indirectly interfering party would also not come into consideration: according to this legal concept a person, who has deliberately, and with sufficient causation, been involved in a breach can also be claimed against for an injunction alongside the person who assumes responsibility for his actions. However, the Regional Court of Kiel (Landgericht Kiel; LG Kiel) ${ }^{16}$ did not accept that such liability was present due to a lack of a legal and actual possibility for the provider to prevent the breach; in a legal respect the contractual relationship to the provider was lacking. In actual fact the blocking by the individual provider can neither prevent nor complicate the access to the content due to the ease of getting around this problem. ${ }^{17}$

\section{The Host Provider}

The legal situation is somewhat more complicated where third party content is made available for use by the provider and is thus saved (so-called Host Providing); according to the wording of the former TDG (Section 5 (2) old version) ("only...if") they should principally not be held responsible for this. There was, however, an exception applicable when the content is known to the provider and it is reasonable and possible given the technology to prevent the circulation of the content. According to the legislator's official basis for Section 5 (2) TDG (old version) the liability for the service provider should only be

${ }^{15}$ OLG Frankfurt, CR 2008, 242 See also LG Frankfurt, MMR 2008, 121; LG Frankfurt, MMR 2008, 344; LG Düsseldorf, MMR 2008, 349; LG Kiel, MMR 2008, 123. But see LG Köln, ZUM 2007, 872.

${ }^{16}$ LG Kiel, MMR 2008, 123.

${ }^{17}$ Schneider, MMR 1999, 571. See also Schneider, MMR 2004, 18; Schnabel, MMR 2008, 281. 
present if he knowingly made unlawful content ready for retrieval; the wording of the TMG is similarly formulated.

According to Section 10 TMG, service providers are not responsible for third party information that they save for a user as long as they have no knowledge of the unlawful act or information. Furthermore, they are not responsible in cases of claims for compensation if they know of no facts or circumstances from which the unlawful act is obvious, or upon discovery of the unlawful act or information they were immediately active in deleting the information or blocking the access thereto. The presence of the elements of "knowledge" and "obvious" unlawfulness are decisive in this case as they form the basis of the claim. The claimant carries the full burden of proving and demonstrating that knowledge was present in the given case; ${ }^{18}$ thereby the liability for the Host Provider shall be restricted to intentional criminal offences and intentional torts. The Higher Regional Court of Dusseldorf (Oberlandesgericht Düsseldorf; OLG Düsseldorf) therefore rejected the Host Provider's duty to examine and decided that liability is first founded with knowledge of the unlawfulness. ${ }^{19}$

The reduction of liability clause under Section $101^{\text {st }}$ Sentence TMG may, however, be inapplicable, especially when a claim for injunction exists against the provider. This exception is valid both when the claim is based on a breach that has already occurred, ${ }^{20}$ and when the injunction serves a precautionary purpose ${ }^{21}$.

It is uncertain when obvious unlawfulness can be assumed. According to the Austrian Supreme Court (Oberste Gerichtshof; OGH), breaches around advertising and standard terms and conditions should exceed that which is clearly recognizable to the layman as being unlawful without the need for inquiry. The Host Providers can therefore only be claimed against with claims - in terms of unfair competition law - for injunction if the breaches by their customers are not apparent to the layman without the need for inquiry.

The legislator actually manages to thwart his own efforts with the rule under Section 10 TMG, namely to compel the provider to self-regulate either internally or through an association. But if the mere knowledge shall suffice as a subjective element, then nobody will be interested in employing staff to review the online content. In fact, the provider will abstain from any self-regulation - and thus remains true to the phrase "nothing seen, nothing heard". This problem has also been acknowledged by the Regional Court of Munich (Landgericht München; LG München), according to which both Art. 14 GG (Grundgesetz; Federal constitution) and the rules in Arts. 8, 10, and 14 WIPO Treaty would

\footnotetext{
${ }^{18}$ BGH, MMR 2004, 166 in connection with § 5 Abs. 2 TDG. But see NJW 1997, 3193, $3198=$ NJW 2002, 921, 925.

${ }^{19}$ OLG Düsseldorf, CR 2006, 682.

${ }^{20} \mathrm{BGHZ}, 158,236,246=\mathrm{CR} 2004,746$ with comments Volkmann - Internet Versteigerung I.

${ }^{21}$ BGH, CR 2007, 523 with comments Rössel - Internet Versteigerung II.
} 
be undermined by the official interpretation of the TMG. Even "turning a blind eye" would lead to the exclusion of liability, and as such can not be permitted. ${ }^{22}$ The Regional Court requires a duty to examine be employed according to the circumstances that form the basis of the unlawfulness. It would have also been at any rate worthwhile to approve a duty to examine for those cases in which a commission of a criminal offence is suggested (for instance the designation of a Newsgroup as "alt.binaries.children-pornography"). Such a duty would have also been consistent with the current legal position in civil and criminal law in cases where there is a blatant risk of violation. However, Art. 15 (1) of the eCommerce Directive expressly refrains from a duty to examine.

Section 10 TMG applies gross legal violations for the knowledge of the unlawfulness. The mere fact that an employee at a data processing facility reviewed a Newsgroup does not mean that he can correctly assess its content i.e. as unlawful. At least as far as the civil liability is concerned, intention - alongside the knowledge and will for the realization of the offense - also includes the awareness of the unlawfulness of the content. The legislator considers it to be necessary that, where claims for compensation are concerned, the provider is aware of the facts and circumstances from which the unlawful information becomes obvious; ${ }^{23}$ this approach is necessary as this assessment is currently difficult to draw from dynamic e-Commerce legislation.

\section{Liability for Links}

\section{Overview}

It is difficult to classify Hyperlinks ${ }^{24}$ in terms of liability given that electronic references do not allow themselves to either be categorized in one of the three aforementioned groups under the TMG, or in the rules provided for in the e-Commerce Directive. This (known) gap in the legislation is based upon the fact that the TMG - as the e-Commerce Directive restricts the regulation of a reduction in liability for Access and Host Providing, as well as for caching, regarding the liability of actors on the internet. Furthermore, it does not allow Hyperlinks or Search engines to be subsumed under the aforementioned categories. One has to note that a hyperlink can never provoke liability, as it is just an electronic link and a technical reference within a HTML-text respectively. Decisive in this respect is the content - at least where manual hyperlinking is concerned - of the statement which is connected to the link - in consideration of its context.

\footnotetext{
${ }^{22}$ LG München I, MMR 2000, 434.

${ }^{23}$ But see Tettenborn et al., supplement for K\&R 12/2001, 1, 32 (arguing that this wording introduces liability for grossly negligible lack of knowledge).

${ }^{24}$ See LG Hamburg, CR 1998, 565 = NJW-CoR 1998, 302. See also AG Berlin-Tiergarten, CR 1998, 111 with comments Vassilaki.
} 
The Local Court of Berlin Tiergarten (Amtsgericht Berlin-Tiergarten; AG Berlin-Tiergarten), ${ }^{25}$ as the first court in Germany, has already correctly pointed out that the responsibility of the person placing the link conforms to the overall statement met by the link. This particular case decided by the Court concerned Angela Marquardt, a member of the Bundestag, who had placed a link on a Dutch server where the banned magazine "Radikal" was also located. The Attorney General accused Marquardt of assisting with the education of a terrorist organization and saw the decisive support in the link to the magazine; a view not held by the Local Court - in terms of criminal law only a specific edition of the magazine "Radikal" is relevant. However, no ascertainment could have been made of whether, and when, the accused obtained knowledge of the input of the unlawful output. The mere continued existence of the link can in any case not form the basis of criminal liability if it can not be positively determined that the accused consciously and deliberately continued to maintain the knowledge and existence of the output.

An accusation of negligence could at the most be brought for the omission of a regular inspection of one's own links, which is however not relevant here. The (short) decision from the Local Court refers to the key question of the meaningfulness the link can have, i.e. if someone shows solidarity with the unlawful content of another by placing the link then he is to be treated as if he were a Content Provider. ${ }^{26}$ In this case there are no reductions in liability that take effect for placing a hyperlink, rather the fundamental idea of Section 7 (1) TMG is applicable here instead. Liability arises according to the general principles: the person who places the link is liable for the content of the linked page as if it were his own.

However, the case would be decided differently if someone does not make the third party content his own as regards the actual content. If someone therefore places a link to a third party website and content - for example out of academic interest - without displaying any solidarity thereto, then he is principally to be judged as an Access Provider so that the assessment under Section 8 TMG thus comes into effect. The liability is normally excluded in such a case.

Where criminal law is concerned, one has to observe the fundamental principle of "in dubio pro reo;" thus where there is doubt - as also decided by the Local Court of BerlinTiergarten - there can principally be no responsibility for placing a link to such content that is relevant in the eyes of criminal law.

\footnotetext{
${ }^{25}$ AG Berlin, CR 1998, 111.

${ }^{26}$ See OLG München, ZUM 2001, 809 (illustrating that the links were combined with names, whereas the linked content contained defamation in terms of Section 186 StGB).
} 
However, the basic concept in Civil law is somewhat different, namely "in dubio contra rerum." Here, the leading decision is that of the Regional Court of Hamburg (Landgericht Hamburg; LG Hamburg) ${ }^{27}$ regarding a collection of links to the so-called Steinhöfel-Hate Pages and a claim by the attorney in question for defamation from the person who had placed the link. In this case, the Regional Court convicted the operator of the website as this person had not sufficiently distanced himself from the defamatory statements from third parties and therefore made these statements his own by making the links available.

Case law has however created differences in the meantime, e.g. a link from a private internet provider to a third party website does not create liability, ${ }^{28}$ whereas liability for so-called "download links" is approved. ${ }^{29}$ The liability can also go as far as making an American parent company liable for a link to the site, which under German law, infringes competition law due to encouragement of third party competition. ${ }^{30}$ Sometimes a duty to secure internet traffic is approved to the effect that the user of a link is also liable for the risk that the reference site is subsequently changed. ${ }^{31}$ All that is requested in order to clarify the legal situation is an express rule in the TMG in the form of a reduction of liability. ${ }^{32}$

\section{Current Jurisprudence on the Liability for Manually Placed Hyperlinks ${ }^{33}$}

The Higher Regional Court of Hamburg (Oberlandesgericht Hamburg; OLG Hamburg) ${ }^{34}$ has correctly presented the view that the "activation" of a banner advertisement does not fall under the TMG and also does not fit with the liability regime set out by the e-Commerce Directive. However, the advertising party can be viewed as an interfering party via the advertisement linked to the banner. This is also the case even when the advertised offer is operated from abroad. These rules are not only pertinent to banners, but also for (manually placed) links.

\footnotetext{
${ }^{27}$ LG Hamburg, CR 1998, 565.

${ }^{28}$ OLG Schleswig, K\&R 2001, 220.

${ }^{29}$ LG Braunschweig, CR 2001, 47.

${ }^{30}$ OLG München, MMR 2002, 625.

31 OLG München, MMR 2002, 625. See also Dippelhofer, JurPC Web-Dok. 304/2002, www.jurpc.de/aufsatz/20020304.htm.

${ }^{32}$ Stenzel, MMR 9/2006, V.

${ }^{33}$ See also www.linksandlaw.de.

${ }^{34}$ OLG Hamburg, CR 2003, 56.
} 
According to the Federal Court of Justice's "Schöner Wetten" ${ }^{35}$ decision, press bodies shall - contrastingly - not be liable for unlawful offers as long as they are used in an editorial article without intention of competition, and the content of the site is not clearly recognizable as being criminal. Under Section 284 StGB (Strafgesetzbuch; German Criminal Code), whomever domestically places a link to unlawful gaming does not necessarily act with the intention of competition; the person placing the link can only be liable as an interfering party if he has breached reasonable duties to examine when constructing and maintaining the link. An addition to editorial content by a link, which does not obviously refer to illegal content, also does not find any liability for an interfering party by reason of Art. 5 GG.

The decision is specifically oriented, however (as the "paperboy" ${ }^{36}$ decision from the Federal Court of Justice ${ }^{37}$ ), around the legislation regulating the press. The Federal Court of Justice $(B G H)$ decided in its decision, which shifted towards copyright law, that placing a hyperlink to data on a third party website (that contains copyright protected creations) does not principally interfere with the right over the duplication of this particular creation. In the Court's view, an entitled party who makes a copyright protected creation accessible via the Internet without any technical safety measures makes the use that can be conducted by the retriever possible. For this reason, no status of copyright interference was created when the access to the creation would have been eased through the use of Hyperlinks (also in the form of Deep Links).

In contrast, non-reduced liability for links is applicable in other fields. In the view of the Higher Regional Court of Hamburg (OLG Hamburg) ${ }^{38}$ a person who thus uses banner ads to provide a link to pages from other companies shall be responsible in competition law for the unlawful linked content as an interfering party. This is at least applicable if the company placing the link thereby advertises to inspect the advertised site for breaches prior to the link being activated.

The Regional Court of Berlin ${ }^{39}$ (Landgericht Berlin; LG Berlin) prohibited the operator of a web portal from using a link to make MP3's of copyright protected songs from a particular band publicly accessible. The judges in this cases held that just the respondent is strictly liable for the breaches as an interfering party because she had the actual and legal

${ }^{35}$ BGH, MDR 2004, 1432 = CR 2004, 613 with comments Dietlein = GRUR 2004, 693 - Schöner Wetten. See also LG Deggendorf, CR 2005, 130.

${ }^{36}$ BGH, NJW 2003, 3406. See also Hoeren, GRUR 2004, 1.

${ }^{37}$ This decision falsely became known as the "Search-Engine" decision.

${ }^{38}$ OLG Hamburg, MMR 2004, 822.

${ }^{39}$ LG Berlin, MMR 2005, 718. 
possibility at her disposal to prevent the infringement of a third party's right through the removal of the link. The same conclusion also arises for the exclusion of liability noted on an internet site: the clause is tailored according to its content to claims for damages which are not subject of the process. The respondent can thus not derive a right for herself that allows for the continuation of an act that has been recognized as being illegal. The Administrative Court of Berlin (Verwaltungsgericht Berlin; VG Berlin) took a similar line for links from a student body as far as these made reference to internet sites with a general political content. ${ }^{40}$ The Regional Court of Stuttgart (Landgericht Stuttgart; LG Stuttgart) ${ }^{41}$ decided that there is no criminal liability for placing links with an extreme right wing body of thought - which would be illegal in Germany - on foreign websites. However, the requirement is that the person placing the link distance himself from the content placed there and the link is part of a report about the occurrence of the events of the day.

The Regional Court of Munich (LG München) ${ }^{42}$ and the Higher Regional Court of Munich $(O L G \text { München })^{43}$ have presided over legal proceedings from eight companies in the music industry against the Heise Magazine Publishers. The reason for the proceedings was a report by heise-online about the new version of DVD copying software. In the original version of this report a link to the company's websites was present alongside a critical appraisal of the statements made by Slysoft, the manufacturer of the software. In the judges' view, heise-online had intentionally assisted in the commission of tortious acts by placing the links to the company's homepage and therefore is liable, as the manufacturer himself, though as an accessory under Section 830 BGB. The judges were also not swayed by the fact that a download of the software was only possible with two further clicks; the sole significance was that the reader of the report would be led directly to the internet site via the link that was in place. As such the placing of the link simply made the location "much more convenient" and thus considerably increasing the risk of a breach of a legally protected interest. The publisher in this case cannot use the freedom of the press by means of Art. 5 (1) $2^{\text {nd }}$ Sentence GG as a way of justifying the placement of the link: this is found in the corresponding provisions of copyright as an effective restriction, and in the present case, has to therefore come in second place to the music industry's proprietary interests.

\footnotetext{
${ }^{40}$ VG Berlin, MMR 2005, 63.

${ }^{41}$ LG Stuttgart, CR 2005, 675. See also OLG Stuttgart, CR 2006, 542 with comments Kaufmann.

${ }^{42}$ OLG München, MMR 2005, 768.

${ }^{43}$ LG München I, CR 2005, 460 with comments Lejeune = MMR 2005, 385 with comments Hoeren. See also LG München I, MMR 2008, 192.
} 
The liability for so-called sponsored links goes beyond the general responsibility for links. Whoever allows a link to be paid for carries increased duties to cease the reference, as long as technological possibilities exist and are reasonable. ${ }^{44}$

\section{Search Engines}

As noted at the beginning, there are also no appropriate provisions for search engines. The reduction of liability clauses under Sections 8-10 TMG is moreover not applicable, and not analogous due to unintended gaps in the legislation, ${ }^{45}$ to the operator of a search engines. The automatically generated links to hits from search engines cannot be subsumed under Section 7 (1) TMG as one's own content is lacking where this reference is concerned. Moreover, the short descriptions provided on the hit pages alongside the link are usually taken from the linked website without any assessment of any kind as to whether it concerns third party content. However, Section 7 (1) TMG is not applicable to third party content, unless liability can be attributed to the snippets generated by the navigational aid. $^{46}$ The application of Section 8 (1) TMG is also excluded where search engines are concerned as navigation aids on the internet are not geared to providing access to information, given that there is a lack in the mere slight influence and neutrality which are characteristic of Access-Providing. Furthermore, the service that is made available by search engines is not comparable with the privileged technical provision of access to a communications network via an Access Provider as contained in Section 8 TMG. In any case it would be conceivable to give recourse to the assessment provided for under in Section 9 TMG. Aside from the fact that an analogous application is excluded due to the intended gaps in the regulations, the transfer of hits by search engines can not however be seen as temporary storage for the increased speed given to the transfer of data. No identical adoption as provided for by Section 9 TMG arises where the entire contents of all the internet sites are concerned due to the analyses carried out by the search engines and the inverted storage of this content in the engine's database-index. ${ }^{47}$

According to general legislation, it is principally the provider of the search engine who is responsible as a normal Content Provider for the hits generated by the actual search engine, despite that the third party web offers are collated automatically and that the results are automatically generated following a search enquiry. As such, he is liable as according to the generally recognized principles of liability for interfering parties as he is subject to certain guarantee and safety - in terms of the Internet traffic - duties through

${ }^{44}$ LG Hamburg, CR 2005, 534.

${ }^{45}$ See Rath, Recht der Internet-Suchmaschinen, 275 et seq.

${ }^{46}$ See Koch, CR 2004, 213, 215. See also Koch, K\&R 2002, 120, 122.

${ }^{47}$ See Köster/Jürgens, K\&R 2006, 108 et seq. (arguing that for the liability of search engines for the list of results). See also Rath, Recht der Internet-Suchmaschinen, 308. 
opening the "source of danger that is Internet search engines." However, according to the general principles, it can also not be expected of the operator of search engines (this is to be taken from the assessments under Sections 7-10 TMG) to continuously carry out inspections of the results that the search engines have automatically collected and indexed. $^{48}$

The absolute exclusion of liability for the operator for hits that he has made available comes only into consideration as long as he has become immediately active in deleting or blocking unlawful information after becoming aware of such information being contained on third party internet sites. However, as there is such an enormous amount of data that is administrated by the search engines one can only apply sufficient knowledge. Therefore the operator is still liable if the unlawful content is, without doubt, easily recognizable and does not require any further inquires. One can presume that such sites are easily recognizable if a legally binding title is present, or that the breach is clear by other means so that questions have to be asked accordingly. ${ }^{49}$

The standards for the operator's liability are, however, also raised in cases where the search engine allows for the list of hits to be manipulated. The reasoning behind this is that the operator of such a search engine is pursuing his own economic interest and as such, can also be responsible (either directly as an interfering party or indirectly due to his own contribution to the cause of the breach) for such manipulation as Paid Listing or Keyword Advertisement, ${ }^{50}$ according to the principles of trademark and competition law. In such a particular case, one has to determine this according to the respective norms concerning liability.

The decisions from case law concerning the liability of the operators of search engines are currently not uniform: e.g., the Local Court of Bielefeld (Amtsgericht Bielefeld; AG Bielefeld $)^{51}$ rejected liability for a breach of copyright where images were used in thumbnails on a search engine. In this case, the Court decided that Sections 7, 8 and 9 TMG would otherwise exclude the respondent's responsibility concerning the copyright as they are special provisions. Furthermore, in the Court's view a reduction in liability arises by means of Section 7 (2) $1^{\text {st }}$ Sentence TMG that is applicable with respect to Section 8 TMG

\footnotetext{
${ }^{48}$ See also LG Frankenthal, CR 2006, 698 (arguing for the decision to be dependent on a balance of interests between those of the creator, to make be able to prevent publication without his consent, and those of the operator of the search engine to maintain the engine).

${ }^{49}$ See Rath, Recht der Internet-Suchmaschinen, 367 et seq.

${ }^{50}$ See Ernst, WRP 2004, 278. See also Ernst, ITRB 2005, 91; Ernst, MarkenR 2006, 57.

${ }^{51}$ AG Bielefeld, CR 2006, 72. See also AG Charlottenburg, decision from 25.02.2005 - 234 C 264/04, available at www.suchmaschinen-und-recht.de/urteile/Amtsgericht-Charlottenburg-20050225.html.
} 
regarding the transmission of images and, concerning the storage, Section 9 TMG. The courts in Hamburg ${ }^{52}$ also adopted a similar line in excluding Google from liability.

In contrast to this, the Regional Court of Berlin (LG Berlin) approved the liability of the operator of a Meta-search engine as far it concerns duties to examine regarding those illegal entries in search results, which have already been subject to warnings about their content. ${ }^{53}$ In February 2006 the Superior Court of Justice of Berlin (Kammergericht Berlin; KG Berlin) ${ }^{54}$ did however overturn the aforementioned injunction that was given by the Regional Court: the court decided that a Meta-search engine is to be equated with a primary navigation aid and therefore should only be liable once when it has knowledge of the unlawful act.

Case law sometimes approves liability in trademark law (for instance the Higher Regional Court of Braunschweig (Oberlandesgericht Braunschweig; OLG Braunschweig), ${ }^{55}$ the Regional Court of Dusseldorf (Landgericht Düsseldorf; LG Düsseldorf), ${ }^{56}$ Regional Court of Hamburg (LG Hamburg) ${ }^{57}$ and the Regional Court of Braunschweig (Landgericht Braunschweig; LG Braunschweig) ${ }^{58}$ under Section 14 (2) MarkenG, especially by so-called "Adword" advertisements for third parties. ${ }^{59}$ According to the view of the Regional Court of Hamburg (LG Hamburg) $)^{60}$ one should only decide that there is no infringement of trademark law where the advertisement is sufficiently designated as such.

There is also no uniform case law in competition law concerning the question of the admissibility of paid listings. One can use two examples to illustrate this point: first the approval by the Regional Court of Hamburg (LG Hamburg) ${ }^{61}$ - prior to a specific decision of liability of a search engine operator for the activation of Paid Listings. Second, the

\footnotetext{
${ }^{52}$ OLG Hamburg, MMR 2007, 601 and MMR 2007, 315.

${ }^{53}$ LG Berlin, CR 2005, 530 = MMR 2005, 324.

${ }^{54}$ KG Berlin, MMR 2006, 393.

${ }^{55}$ OLG Braunschweig, CR 2007, 177.

${ }^{56}$ LG Düsseldorf, CR 2006, 205.

${ }^{57}$ LG Hamburg, MMR 2005, 631

${ }^{58}$ LG Braunschweig, K\&R 2006, 143.

${ }^{59}$ See LG München, CR 2007, 467, 468 (discussing the admissibility of a use of brands and trademarks as an Adword).

${ }^{60}$ LG Hamburg, MMR 2005, 629.

${ }^{61}$ LG Hamburg, decision from 14.11.2003- 3120 887/03, www.jurawelt.de/aktuelles/nationales/8839.
} 
decision by the Regional Court of Munich (LG München), ${ }^{62}$ which - in an almost identical case - rejected the liability of the operator by referring to the unreasonableness of a duty to examine.

\section{Liability for Other Intermediaries}

The liability of other intermediaries is also something that is considered by legal practice. It is undisputed that whomever offers products for sale in an online auction is responsible for the legality of his offer e.g. concerning trademark law, even if it only concerns a private sale. ${ }^{63}$ This principle is also applicable for online sellers who are liable as the owner for all of the breaches of trademark law that have taken place within the scope of the business' activities; they are even liable if the breach has been committed by an agent. ${ }^{64}$ It is, however, disputed whether the operator of an online auction has to deem offers by third parties as being his own in terms of the content. ${ }^{65}$ Many courts are also currently occupied with proceedings in which the firm "Rolex" is claiming against auction houses such as eBay and Ricardo due to the sale of replica Rolex watches, and thus concerning a breach of trademark law. The auction houses in these cases view themselves as being Host Providers who first have to become active following information by Rolex. The Regional Court of Cologne (Landgericht Köln; LG Köln), however, sided with the claimant and determined the offers to be the "own" content of the respective auction house given that at least the headings of the offers are presented as being one's own content. It is viewed that one's own content is also present if, from the user's perspective, a combination takes place to the extent that the service provider and third party content appear as one. In this respect, Ricardo was subject to an injunction as a Content Provider due to the breaches of trademark law; ${ }^{66}$ however, the Higher Regional Court of Cologne (Oberlandesgericht Köln; OLG Köln) overturned this decision. ${ }^{67}$ The Federal Court of Justice (BGH) has, nevertheless, now decided that the operator of a platform for online auctions can be subject to an injunction where parties use this platform to offer fake goods for sale. ${ }^{68}$ The Court emphasized in this case that the provisions of the TMG that provide for a reduction in liability for "hosting" services (services which allow third party content to be stored with

\footnotetext{
${ }^{62}$ LG München I, MMR 2004, 261.

${ }^{63}$ LG Berlin, CR 2002, 371 with comments Leible/Sosnitza.

${ }^{64}$ OLG Köln, CR 2007, 184.

${ }^{65}$ LG Köln, CR 2001, 417.

${ }^{66}$ See LG Hamburg, CR 2002, 919.

${ }^{67}$ OLG Köln, MMR 2002, 110 with comments Hoeren = CR 2002, 50 with comments Wiebe $=$ K\&R 2002, 93 with comments Spindler 83. See also LG Düsseldorf, MMR 2003, $120=$ TKMR 2003, 38 with comments Leupold.

${ }^{68}$ BGH, MMR 2004, 668.
} 
the operator) are applicable for the claim to damages, but not to the claim for an injunction, ${ }^{69}$ and, as such, there is the consideration that the respondent can be liable as an interfering party. This claim requires commercial trade ${ }^{70}$ and a reasonable possibility for the operator to check, so as to stop the breach of trademark law. It is not expected of him to check each offer, which is automatically directly placed online by the offeror, for whether they breach the protected rights of third parties. As such, a preliminary injunction can not be valid in the event of a breach of a protected right that is not (yet) present; ${ }^{71}$ however, if the operator becomes aware of the breach then he not only has to immediately block the access to the specific offer, but also ensure that no further corresponding breaches are committed. The Federal Court of Justice $(B G H)$ has, however, denied a claim for damages against the operator of the platform. ${ }^{72}$ If the auction house becomes aware of a breach, then it not only has to block the access to the respective offer, but also has to ensure that it makes use of reasonable and technologically possible measures so as to prevent further breaches. ${ }^{73}$

According to the view of the Higher Regional Court of Frankfurt (Oberlandesgericht Frankfurt; OLG Frankfurt), ${ }^{74}$ the account owner is also liable as far as he has given his account details to a third party, who then subsequently uses this account to auction replicas of copyright protected goods. The account owner is, nevertheless, passively legitimated even if he did not offer the goods himself. This follows from the case of liability for interfering parties as the account owner has deliberately, and with adequate causation, contributed to the breach by allowing access to his account. Even when the duties to examine may not be overstretched for the account owner, he is still responsible for the act by the third party if he did not concern himself with the goods sold by the third party using his account.

In the view of the Higher Regional Court of Koblenz (Oberlandesgericht Koblenz; OLG Koblenz), ${ }^{75}$ the so-called admin-c ${ }^{76}$ (the administrative contact named by the owner of the

\footnotetext{
${ }^{69} \mathrm{BGH}, \mathrm{MMR} 2007,507$ - Internetversteiegerung II (illustrating that the preliminary injunction is included).

${ }^{70}$ See OLG Frankfurt a.M., MMR 2005, 458 (discussing the question of an offer in an auction brings about a commercial transaction).

${ }^{71} B G H$, MMR 2007, 507 - Internetversteigerung II. See also BGH, MMR 2007, 634 (discussing writings harmful to the young available on eBay).

${ }^{72}$ BGH, MMR 2004, 668.

73 See LG Hamburg, MMR 2005, 326 with comments Rachlock. See also OLG Brandenburg, CR 2006, 124 (discussing infringements of naming rights).

${ }^{74}$ OLG Frankfurt a.M., CR 2005, 655. See also LG Bonn, CR 2005, 602 (discussing infringements against the UWG); OLG Stuttgart, GRUR-RR 2007, 336.

${ }^{75}$ OLG Koblenz, CR 2002, 280 = MMR 2002, 466 with comments Ernst/Vallendar.
} 
domain), is not liable for breaches of branding rights that occur in connection with a particular domain. The admin-c may indeed be the DENIC's contact person, though the person who is legally responsible for the breach is however the owner of the domain. This view contradicts that of the Higher Regional Court of Munich (OLG München), which states that the admin-c's liability as an interfering party is justified by the fact that he has a direct possibility to influence the name of the domain. ${ }^{77}$ The Superior Court of Berlin (KG Berlin) approved a duty to examine on the admin-c in those cases in which the owner of the domain and the operator of a meta-search engine have previously and unsuccessfully requested to delete those entries in the search results that infringe upon privacy rights or in cases where this request would be unsuccessful from the outset. ${ }^{78}$ In light of the existing legal uncertainty, those persons who make themselves available as an admin-c should pay attention prior to the registration of the domain that no legal objections exist against the allocation of the domain.

In addition, the Federal Court of Justice ${ }^{79}(B G H)$ has, in this respect, expanded the liability of the domain provider. If a request is made to someone for an internet presence to be created under a particular domain name, and this person subsequently registers the domain for himself, then he can be compelled to cease using the domain name and to consent to the deletion of the registration. This approach follows the consideration that the person has purposely impeded a competitor as under Section $4 \mathrm{Nr}$. 10 UWG and breached one of his pre-contractual duties. The view of the Higher Regional Court of Hamburg (OLG Hamburg) is that the service provider named in the contact details is also responsible for the content remaining in the sub-domain that is hidden to the user. ${ }^{80}$ The liability for the operator of a domain name is dependent upon the point of positive recognition - as affirmed by the Regional Court of Dusseldorf (LG Düsseldorf). ${ }^{81}$ According to this principle, liability can only be supposed following the point in time in which the provider of a domain-exchange ${ }^{82}$ becomes positively aware of the breach of trademark law. Thus it is not reasonable for the operator of such an exchange to go beyond this and check all of those stored domains for breaches of trademark law.

\footnotetext{
${ }^{76}$ See Hoeren/Eustergerling, MMR 2006, 132. See also Wimmers/Schulz, CR 2006, 754.

77 OLG München, MMR 2000, 577. See also OLG Stuttgart, MMR 2004, 38; LG München I, CR 2005, 532; AG Bonn, MMR 2004, 826 (for the field of the UWG); LG Hamburg, decision 15.3.2007 - 3270 718/06.

${ }^{78}$ KG Berlin, CR 2006, 778.

${ }^{79}$ BGH, CR 2005, $510=$ MMR 2005, 374 Literaturhaus.de.

${ }^{80}$ OLG Hamburg, MMR 2005, 322.

${ }^{81}$ LG Düsseldorf, MMR 2008, 254.

${ }^{82} \mathrm{~A}$ domain exchange refers to the concept of making unused domain names available for purchase.
} 
The parties are also liable for sending political e-Cards over their server. ${ }^{83}$ Even if the party did not send the e-mails himself, he is to be viewed as an (indirect) interfering party in the event that the sending of e-mails via a so-called e-Card function is present on his homepage, and control does not take place over whether the sender is entitled to do so. It is possible that the user can hide behind the provider of the e-Card function so as carry out the unlawful interference with a third party's right as long as an abuse of a right via e-Cards can not be excluded with sufficient certainty. As such, it is therefore expected that the user abstain entirely from using this mechanism if necessary. Whoever does not send a newsletter as a blind copy, but rather sends it to numerous e-mail addresses listed in the address field, therefore plays a role in distributing the address list and is an (indirect) interfering party. ${ }^{84}$

The operator of an internet guestbook can be subject to particularly severe liability. ${ }^{85}$ Whoever picks out an attorney's dissuasive behavior as a theme for his guest book has to therefore expect entries of a manner that are harmful to the subject's reputation. The operator is thus obliged to regularly check the entries, otherwise he will therefore make third party content his own and will be equated with a Content Provider in terms of Section 7 (1) TMG. The liability for e-mail Spam is assumed by the lessor of the subdomain; whoever lets sub-domains to a provider of eroticism is liable for the e-mail Spam that are sent by this provider. ${ }^{86}$ The Regional Court of Cologne (LG Köln) approved the liability of a portal operator for classified advertisements that were obviously unlawful. ${ }^{87}$ The portal operator shall also be liable if he has read though the advertisement and has failed to notice that these breach the right to privacy. ${ }^{88}$

Whoever has been adjudged to cease making comments that are harmful to one's reputation has to ensure that the comments are not to be found in the online-archive. The operator of a forum is similarly obliged to compensate for the litigation cases that arise if the individual sends an e-mail demanding that a third party's defamatory photographs are deleted and the responsible operator does not comply with the request within the statutory time limit. ${ }^{89}$ In any case, the operator of the forum is also subject to increased liability duties. Thus, according to the view of the Regional Court of Hamburg (LG

\footnotetext{
${ }^{83}$ LG München I, MMR 2003, 483; AG Rostock, MMR 2003, 345.

${ }^{84}$ OLG Düsseldorf, MMR 2006, 681.

${ }^{85}$ LG Düsseldorf, MMR 2003, 61.

${ }^{86}$ AG Leipzig, decision from 27.2.2003- 02 C 8566/02.

${ }^{87}$ LG Köln, CR 2004, 304.

${ }^{88}$ LG Köln, MMR 2004 with comments Christiansen. See also Spieker, MMR 2005, 727.

${ }^{89}$ AG Winsen/Luhe, CR 2005, 722.
} 
Hamburg), given that the operator of the forum has to "automatically or manually preliminarily" examine the legality of the texts entered by the third party, the operator is also responsible as an interfering party for the unlawful postings by a third party in onlineforums if he does not have any knowledge of the specific entries. Such a duty to examine was rejected by the Higher Regional Court of Hamburg (OLG Hamburg) following appeal: the operators just simply have a special duty to examine the threads in the specific forum if he has either foreseeably provoked unlawful contributions from third parties through his own behavior, or at least one severe breach has been named to him, and therefore the danger of further unlawful acts by an individual user has already become substantiated. The operator is, however, compelled to immediately delete the respective entry as soon as he becomes aware of the breach. ${ }^{90}$

On similar lines the Regional Court of Hamburg (LG Hamburg) ${ }^{91}$ approved liability for interviews: the press carry full responsibility for the comments made by interviewees as according to the regulations of liability for distributors. If one would allow the form of an interview to be sufficient disassociation, or would reduce a duty to examine to especially severe interferences with privacy rights, then - according to the view of the Court comments by the media corporations would be allowed to be distributed in the form of an interview (without disassociation as to the content), which would otherwise be inadmissible in other journalistic texts. As such, this would lead to media corporations using an interview to spread untrue statements of fact (up until particularly severe infringements of privacy rights) without being subject to sanctions. This would have created the risk that affected individual would lose his opportunity to enforce a prohibition on the spreading of untrue statements. The view in question no longer has anything in common with the former rules concerning the liability of the media and no longer wellgrounded in the German legal system. In its decision, the Higher Regional Court does not view the rulings of other courts (including the Federal Court of Justice $(B G H)$ ), and obstinately justifies a particular path that is used by clever attorneys as a means of getting the case to Hamburg with regard to the respective courts where the Internet is concerned. One can only hope that the higher courts gradually bring the Higher Regional Court to sense.

According to the view of the Higher Regional Court of Hamburg (OLG Hamburg) the internet search engine "Google" is not liable for AdWords (banner ads from third parties) due to a possible infringement of trademark rights. ${ }^{92} \mathrm{~A}$ trader is jointly responsible as an interfering party for the breaches of trademark rights carried out by his affiliates; this is

\footnotetext{
${ }^{90}$ LG Düsseldorf, CR 2006, 563.

${ }^{91}$ LG Hamburg, AfP 2008, 414.

92 OLG Hamburg, MMR 2006, 754. See also LG Lepzig, MMR, 2005, 622. See generally Meyer, K\&R 2006, 557; Schaefer, MMR 2005, 807.
} 
also applicable if the trader expressly declares in the terms and conditions of the affiliates program that the affiliate is to observe the trademark rights of third parties. The liability as an interfering party is only excluded when the trader makes a corresponding list of the relevant trademarks available to his affiliates and the use of these terms would be expressly prohibited in the contract. ${ }^{93}$

In a claim by a company under Section $1001^{\text {st }}$ Sentence UrhG (concerning acts by the employees or agents of a company that violate copyright law), the claimant must prove the company's relationship even with computers used for work-related tasks. ${ }^{94}$ Even if no firewalls are installed on company computers that are made available to employees (in this case an intern at a radio station), this does not infer vicarious liability (Section 831 BGB) of the bodies of the company for breaches of copyright if there is no indication that the employees are acting unlawfully (in this case the exchange of music files via file sharing programmes). ${ }^{95}$ In any case, there is no general experience that employees will use those computers that are made available to them for breaching copyright laws.

In addition, the owner of the internet connection is liable for each fraudulent use of his internet connection as according to the principles of liability for interfering parties. ${ }^{96}$ The owner has the duty to inform himself of the risks and to monitor the user's actions. ${ }^{97}$ The owner has to at least make use of safety measures that permits the use of standard software, for instance creating user accounts with passwords. ${ }^{98}$ However, the higher courts have recently disagreed with this strict view. ${ }^{99}$ The duty to examine for breaches of copyright does not arise for wireless Internet used in the home, provided that the owner of the connection does not know of, or could have known of, any earlier breaches of this kind by the user, or of other indications for the intention to cause a breach of this kind.

The creator of P2P software is also liable as an interfering party as long as his product can be used to breach copyright laws; ${ }^{100}$ the use of a disclaimer does not regularly exclude this liability.

${ }^{93}$ LG Köln, CR 2006, 64. See also LG Berlin, MMR 2006, 118. But see LG Hamburg, CR 2006, 130.

${ }^{94}$ OLG München, CR 2007, 389.

${ }^{95}$ LG München I, MMR 2008, 422.

${ }^{96}$ LG Hamburg, CR 2006, 780.

${ }^{97}$ LG Hamburg, MMR 2006, 700. See also LG Frankfurt, MMR 2007, 675.

${ }^{98}$ OLG Düsseldorf, MMR 2008, 256.

${ }^{99}$ OLG Frankfurt, MMR 2008, 169. See also CR 2007, 394 (dismissing the connection owner's liability for acts by family members who are of full age).

${ }^{100}$ OLG Hamburg, MMR 2006, 398. 
Usenet Services, like Access Providers, are not subject to liability. ${ }^{101}$ As the required breaches of examination duties may not be exceeded, it is the view of the Higher Regional Court of Dusseldorf (OLG Düsseldorf) that a possibility for the provider to examine has to be entirely possible or reasonable. In doing so, one has to also observe the factualtechnological conditions. This has the consequence for Usenet Providers that makes it hardly possible "to delete unlawful third party content from the Usenet." In comparison to Internet forums, the operator of a News server, which due to "mirroring" redundantly saves the Usenet data, the operator can only delete those data which are temporarily stored on its own server. However, the data will again be transferred to the server upon a new request by the user, and is possible as long as the respective information is still retrievable in the Usenet. According to Section 9 TMG there are therefore even considerably fewer possibilities that arise for providers to remedy an error as compared to Host Providers.

In addition, the operator of a domain exchange is not liable for trademark infringements due to the domains that are located there. ${ }^{102}$

An employee is principally not liable for the illegal participation on a file sharing system by one of his employees. ${ }^{103}$

The international development in the field of P2P is also most fascinating: French draft legislation provides that citizens who download unlicensed copies of digital media products from the internet will have their access to the internet blocked in the future. ${ }^{104}$ However, this draft legislation arose after the European Parliament voted, with a slight majority, against the introduction of blocking access to the Internet. ${ }^{105}$ The draft legislation provides for the creation of a government authority (HADOPI/Haute Autorite pour la diffusion des oeuvres et la protection des droits sur Internet) that contracts supposed infringers of copyright, warns them, and - if necessary - instructs that their access to the Internet be blocked. If the internet provider again makes an internet connection available to the user, then he can be obliged under statute to install filets. Furthermore, fines up to 5,000 Euro are also threatened. ${ }^{106}$

${ }^{101}$ OLG Düsseldorf, MMR 2008, 254. See also LG München I, MMR 2007, 453.

${ }^{102}$ LG Düsseldorf, MMR 2008, 349.

${ }^{103}$ LG München I, MMR 2008, 422.

${ }^{104}$ ECO, MMR 2/2009, XXI.

${ }^{105}$ Greve/Schärdel, ZRP 2009, 55.

${ }^{106}$ Details can be obtained from this website: http://www.squaringthenet.org/en/exclusive-the-latest-olivenneslaw-draft. 


\section{Conclusions}

Germany can refer to an extensive case law regarding Internet liability. However, the structure of these court decisions is not very clear and is incompatible with the liability system implemented in the EU Ecommerce directive (see above). Changes are necessary: the Ecommerce directive needs to be adapted to "new" phenomena like search engines, hyperlinks or Web 2.0 services. Thus we have to wait and see what Brussels does. 
